\title{
IAMJ
}

INTERNATIONAL

AYURVEDIC

MEDICAL JOURNAL

\section{A COMPREHENSIVE STUDY OF SWETA MUSALI (ASPARAGUS ADSCENDENS WILLD.) IN BRIHATTRAYI AND NIGHANTU: A REVIEW}

\section{$\underline{\text { Naithani Ekta }}^{1}, \underline{\text { Purohit Suman }}^{2}, \underline{\text { Vashisht Kiran }}^{3}$}

${ }^{1}$ A former Product Manager at AIMIL Pharmaceuticals, MD (AYU), New Delhi, India

${ }^{2}$ Assistant professor, Department of Rasa-Shastra \& Bhaishjya Kalpana, Glocal Ayurvedic Medical College, Saharanpur, UP, India

${ }^{3}$ Assistant Professor, Department of Dept. of Dravyaguna, Uttarakhand Ayurveda university, Dehradun, Uttarakhand, India

Corresponding Author: dr.ekta.naithani@gmail.com

https://doi.org/10.46607/iamj09p4062020

(Published online: September 2020)

Open Access

(C) International Ayurvedic Medical Journal, India 2020

Article Received: 15/09/2020 - Peer Reviewed: 24/09/2020 - Accepted for Publication: 26/09/2020

Check for updates

\section{ABSTRACT}

Brihattrayi (Greater triad) is one of the widely used and highly believed referral sources for Ayurvedic knowledge which includes three important treatises of Ayurveda which are Charaka Samhita, Sushruta Samhita, and Ashtanga Hridya. In Charaka Samhita and Sushruta Samhita there is no clear cut description of Sweta musali. The Term Musali has been used for the first time in Ashtanga Hridya, which has been indicated for local application in Neelika (Blue moles) and Vyanga (Facial melanosis) as Complexion promoting. In Nighantu period the references for Sweta musali has been found at many places. This article reviews the description of Musali, various formulations, therapeutic indications, and the diverse mention of Sweta musali in Brihattrayi and Nighantu.

Keywords: Brihattrayi, Sweta musali, Nighantu, Formulation, Ayurveda, Asparagus adscendens. 


\section{INTRODUCTION}

Asparagus adscendens Willd is the source for the Sweta musali, belongs to the Liliaceae Family is also known as Shatavar bhed which is used to treat female disorders, seminal weakness, impotency and as a nutritive tonic. ${ }^{[1]}$ It is distributed between W. Himalayas and Punjab to Kumaon upto $5300 \mathrm{ft} .{ }^{[2]}$ It is a sub-erect prickly shrub with white tuberous roots. Stems are tall, stout, smooth, white; Spines are stout, straight, 1.3$2 \mathrm{~cm}$ long; Cladode Dense tufts of 6-20. 1.3-5 cm long, slender, filiform, terete Shift, sub-erect or curved; Flower in many-flowered racemes, whitish; Fruit 6-8 mm diameter, one-seeded. ${ }^{[3]}$ There are two varieties of Musali. ( i ) Kali Musali- curculigo orchoides. (ii) Sweta Musali-Asparagus adscendens- belongs to the Genus of Shatavari. Nowadays Chlorophytum borivilanum is cultivated and sold in the market as Sweta Musali. ${ }^{[4]}$ The root was found to contain fat, protein, Saponin, carbohydrate (including uronic acid and free sugur), inorganic matter, and ash. The carbohydrate fraction was made up of free sugur, mucilage, hemicelluloses, and insoluble polysaccharides. The mucilage contained mannose, glucose, xylose and uronic acid. ${ }^{[5]}$ Sweta musali (Asparagus adscendens Willd.) In Brihattrayi

Charaka Samhita:- (1000 B.C. TO $4^{\mathrm{TH}}$ Century A.D. $)^{3}$

In this classical text, a large number of drugs have been used for therapeutic purpose but no reference has been found related to Musali / Sweta musali.Taalmuuli considered as Krishna musali has been indicated for smoking along with Manahshila and some other drugs in the management of Swasa kasa. (C.S.Chi.18/75) ${ }^{[6]}$

Sushruta Samhita:- (1000 B.C. TO $5^{\mathrm{TH}}$ Century A.D. $)^{4}$

Acharya Sushruta has indicated Taalpatri and Taalmuuli in various preparations and formulations, but has not given any explanation about Sweta musali. ${ }^{[7]}$

Table 1:

\begin{tabular}{|r|l|l|l|l|}
\hline S.No. & Name & Partused/Preparation/ Formulation & Indication & References \\
\hline 1. & Taalpatri & Churna/kshar kalpana & - & S.S.Su.11/15 \\
\hline 2. & Taalpatri & Utsadana & Vrana & S.S.Su.36/31 \\
\hline 3. & Taalmuuli & - & Sarkara & S.S.Chi.7/18 \\
\hline 4. & Taalpatri & Pralepa & Vaataj granthi & S.S.Chi.18/5 \\
\hline 5. & Taalmuuli & Kalka & Unmanth,paali rog & S.S.Chi.25/18 \\
\hline 6. & Taalmuuli & Dhumpan yoga & Kasa & S.S.Chi.18/74 \\
\hline 7. & Taalmuuli & Kolmajjadh Streeyo yoga & Swasa & S.S.U.51/38 \\
\hline
\end{tabular}

Ashtang Hridaya: (700AD) ${ }^{5}$

The term Musali has been used for the first time in Ashtang Hridya and Musali has been indicated for local ap- plication in Neelika and Vyangaa as Complexion promoting. In this text, three preparations by the name of Taalpatri and one by the name of Taalparni have been mentioned. ${ }^{[8]}$

Table 2:

\begin{tabular}{|r|l|l|l|l|}
\hline S.No. & Name & Partused/Preparation/Formulation & Indication & References \\
\hline 1. & Taalpatri & Tiksna Kshar & Medjanya arbud & A.H.Su.30/21 \\
\hline 2. & Taalpatri & Taila & Unmanth & A.H.U.18/45 \\
\hline 3. & Musali & Vyangaaadinasak ubtan & Vyangaa & A.H.U.31/21 \\
\hline 4. & Taalpatrika & Churna & Sarakara & A.H.Chi.11/28 \\
\hline 5. & Taalparni & Lepa & Ekang shoph & A.H.Chi.17/26 \\
\hline
\end{tabular}


Table 3: Classification Of Sweta musali (Asparagus adscendens Willd.) In Various Nighantu

\begin{tabular}{|l|l|l|}
\hline S.No. & Nighantu & Varga \\
\hline 1. & Dhanvantari Nighantu & \\
\hline 2. & Shodhala Nighantu & Laxmanadi varga \\
\hline 3. & Madanpaal Nighantu & Shaka Varga \\
\hline 4. & Kaiyadeva Nighantu & Kanda Varga \\
\hline 5. & Bhavaprakasha Nighantu & Guduchiyadi Varga \\
\hline 6. & Raj Nighantu & Mulakadi Varga \\
\hline 7. & Priya Nighantu & Sharadi Varga \\
\hline 8. & Nighantu Adarsh & Lashunadi Varga \\
\hline
\end{tabular}

\section{Nighantu Period}

a) Dhanvantri Nighantu:- $\left(10^{\text {th }}-13^{\text {th }}\right.$ Century A.D. $)$ In Dhanvantri nighantu, drugs are classified into seven Vargas but there is no description of Sweta musali or Krishna musali.

b) Shodhala Nighantu:- $\left(12^{\text {th }}\right.$ Century A.D.) In Shodhala nighantu Musali has been described in Lakshmanadi Varga and Karviradi Varga. In Lakshmanadi Varga synonyms of Sweta musali are Muslya, Musali, Sukanda, Taalmuuli, Kharjuri, and Atisarnashani. Acharya Shodhala has described the properties of Musali in Karviradi Varga. According to him, it has Madhura rasa, Madhura vipaka, Sheeta virya and it is useful in Vaata-pitta disorders. It is Vrishya, stimulates digestive power, and provide Sthairya and Mardava. These properties in Guna Snagrah indicate that this is the description for Sweta musali by Acharya Shodhala. ${ }^{[9]}$

c) Madanapaal Nighantu:- $\left(14^{\text {th }}\right.$ Century A.D.) In Madanapaal nighantu Musali has been described in Shaka Varga with synonyms like Musali, Taalmuulika, Kharjuri, Kanchanpushpika, Taalpatri, Vrishyakanda. According to this Nighantu, it has Tikta rasa, Guru guna, Ushna virya and it is useful in Vaata roga, Arsha roga. It seems that these are the Properties of Krishn musali. There is no description of Sweta Musali is given. ${ }^{[10]}$

d) Kaiyadeva Nighantu:- $\left(15^{\text {th }}\right.$ Century A.D.) According to Kaiyadeva nighantu Sweta musali has been described in Aushadhi Varga as Asparagus adscendence with synonyms like Musali, Kharjuri, Taalmuulika, Mahavrisha, Vrishyakanda, Hiranyapuspi. According to him, it has Ushna virya. ${ }^{[11]}$ e) Bhavaprakasha Nighantu:- $\left(1^{\text {th }}\right.$ Century A.D.) Acharya Bhava Mishra described Sweta musali in Guduchiyadi Varga. According to Bhavaprakasha Nighantu Musali and Taalmuuli both are Krishna musali and gives two types of Musali with its botanical source, properties, Chemical composition, synonyms, and prescribed dose. Krishna musali has been identified as Curculigo orchioides While Sweta musali identified as Asparagus adscendens and Chlorophytum borivilianum. ${ }^{[4]}$

f) Raj Nighantu:- $\left(\mathbf{1 7}^{\text {th }}\right.$ Century A. D.) There are two types of Musali mentioned in Raj Nighantu, One is Krishna musali and the other is Sweta musali. Both the Musali has been described in Mulakadi varga. Synonyms for Musali are Musali, Taalmuuli, Taalmuulika, Godhadi, Hemapushpi, Bhuttali, Dirgha, kandika. The Krishna Musali has been identified as Curculigo orchoides and Sweta Musali as Hypoxis orchoides by the commentator of the book. ${ }^{[12]}$

g) Priya Nighantu:- $\left(\mathbf{2 0}^{\text {th }}\right.$ Century A. D.) In this Sweta musali has been described in Sharadi Varga and identified as Asparagus adscendens. According to this Nighantu, it has Tikta rasa. It is therapeutically used in pitta disorder and it is Vrishya and Rasayana. ${ }^{[13]}$

h) Nighantu Adarsh:- $\left(2^{\text {th }}\right.$ Century A. D.) In this Sweta musali has been described in Lashunadi Varga with synonyms like Musali, Mahavrisha, Vrishyakanda, Duramari. According to this Nighantu, it has Madhura Rasa, Sheeta Virya, Madhura Vipaka. It is Vrishya and therapeutically used in pitta disorder. It seems that this description is for Sweta musali and identified as Asparagus adscendens. ${ }^{[14]}$ 


\section{DISCUSSION}

Asparagus adscendens willd is the source for Sweta musali. It is a well-known drug that is commercially used in the market and mentioned in the classical textbooks and used in many diseases and formulations such as Musalyadi churna, Madhu mandur etc. ${ }^{[15]}$ In Charak Samhita there is no reference has been found related to Musali/ Sweta musali. Taalmuuli is considered as Krishna musali. Acharya Sushruta has indicated Taalpatri and Taalmuuli in various preparations and formulations. But has not given any explanation about Sweta musali. The term Musali has been used for the first time in Ashtang Hridya, indicated for local application in Neelika and Vyangaa as complexion promoting. Some identify A. adscendens as Maha Shatavari. But this plant is originally considered as Sweta musali. ${ }^{[16]}$ In Nighantu references for Sweta musali is available in many Nighnatus and it is known for $R a$ sayana and Vajikarana as it is useful in increasing sperm count. In Bhavaprakash nighantu, the Sweta musali is describes in Guduchyadi Varga along with there synonyms, botanical name, family, morphology, chemical constituent, properties, therapeutic uses, and doses. In this it is indicated especially for Napunsakta (Impotency).

According to my view, Musali is of two types, one is Sweta musali - Asparagus adscendens and the other is Krishna musali-curculigo orchoides. Again Sweta musali is classified into Chlorophytum arundinaceum and Chlorophytum borivillianum. ${ }^{[17]}$ Taalmuuli is a synonym for Krisna musali. Both the Musali belong to different families and have different properties i.e Sweta musali is Sheeta virya while Krishna musali is Usna virya but both are showing the rejuvenation (Rasayana) and aphrodisiac (Vrishya) actions.

\section{CONCLUSION}

The main objective of the present study was to give a review for Sweta musali in Brihattrayi and Nighantu is important to fulfill knowledge of the herb about its preparations and formulations available in Ayurvedic texts so it can be used according to their properties. In Brihattrayi only Ashtang Hridaya which the third important treatises of Ayurveda have references related to
Musali and references also available in different nighantu. By this, we can know the proper uses and indications of Sweta musali in many diseases. In Ashtanga hridiya, it is indicated for the diseases-related to the skin and also mentioned it to promote skin complexion. In many Nighantus, it's aphrodisiac (Vrishya) properties have been described and it shows its importance in male infertility. So it can be used as a general male tonic because of its Vrishya guna. Other than this it also improves digestion, gives strength to the body and muscles.Beside this further studies also required related to the Sweta musali as it can be used as a general tonic by anyone. As we know Ayurveda is a science of life and there is no side effect of an ayurvedic drug if taken properly.

\section{REFERENCES}

1. Mahesh Kawale, Sandip Ankoliya, R. Saravanan, Tushar Dhanani and P. Manivel Pharmacognostical and physicochemical analysis of Asparagus adscendens Buch. Ham. ex Roxb. (Shweta musali). Journal of Pharmacognosy and Phytochemistry 2014; 3(4): 131-139.

2. The Wealth of India Raw Material volume 1 Series(AB B). National Institute of Science Communication and Information Resources CSIR, New Delhi-110 012.http://www.niscair.res.in/

3. Dr. J.L.N Sastry, Dravyaguna Vijana, Part-2,Chaukhambha Orientalia, Varansi, $2^{\text {nd }}$ edition 2005 Page no541

4. Padma Shri Prof. K.C. Chunekar A.M.S and Dr. G.S Pandey A.M.S, Bhavaprakasha Nighantu,Chapter 4, Guduchyadi Varga Chaukhambha Bharati Academy, Varansi Reprint- 2015, Page No -377.

5. A.K. Gupta and Neeraj Tandon, Indian Medicinal Plant Volume-3, Indian Council of Medical Research, Ansari Nagar, New Delhi, India, 2004, Page No -225.

6. Prof. Pt. Kasinath Sastri And Dr. Gorakhnatha, Chaturvedi, The Charak Samhita Part $-1 \&$ 2, Chaukhambha Bharati Academy, Varansi Reprint- 2013.

7. Dr. Ambikadatt sashtri, Sushruta Samhita, Part $-1 \& 2$, Chaukhambha Sanskrit Sansthan, Varansi ,Reprint 2016.

8. Kaviraj Atridev Gupta, Astanghrdayam, Chaukhambha Prakashan, Varansi, Reprint-2018. 
9. Prof. R.R. Dwivedi, Shodhala Nighantuh, Naam Sangreh part -1, Chapter 7, Laxamandi Varga, Chaukhambha Krishnadas Academy, Varansi, Page no- 137 $\& 264$.

10. Prof. Gyanendra Pandey, Madanpal Nighantu,Chapter 7, Shaka Varga, Chaukhambha Orientalia, Varansi, $1^{\text {st }}$ edition- 2012, Page no- 191.

11. Dr. P.V. Sharma and Dr. Guruprashad Sharma, Kaidev Nighantu, Chapter 1, Aushadi Varga Chaukhambha Orientalia, Varansi, Reprint-2013, Page no- 643.

12. Dr. Indradeva Tripathi, Raj Nighantu, Chapter 7, Mulakadi Varga, Chaukhambha Krishnadas Academy, Varansi, Page no- 208.

13. Prof. P.V. Sharma, Priya Nighantu Chaukhambha Surbharti Prakashan, Varansi, Edition- 2004, Page no126.

14. Bapalala G. Vaidhya, Nighantu Adarsha Vol. 2, Lasunadi Varga, Chaukhambha Bharati Academy, Varansi, Reprint- 2019 Page no- 642.

15. Vaidhya Laksmipati Shastri, Yogaratnakar, Vidhyotani hindi Teeka Sahit, Chaukhambha Prakashan, Varansi, 2014
16. Dr. J.L.N Sastry, Dravyaguna Vijana,Part-2, Chaukhambha Orientalia, Varansi, $2^{\text {nd }}$ edition 2005 Page no541

17. Padmshri Prof. K.C. Chunekar A.M.S and Dr. G.S. Pandey A.M.S, Bhavaprakasha Nighantu, Chapter 4, Guduchyadi Varga Chaukhambha Bharati Academy, Varansi Reprint- 2015, Page No -377.

\section{Source of Support: Nil}

\section{Conflict of Interest: None Declared}

How to cite this URL: Naithani Ekta et al: A Comprehensive Study of Sweta Musali (Asparagus Adscendenswilld.) in Brihattrayi and Nighantu: A Review. International Ayurvedic Medical Journal \{online\} 2020 \{cited September, 2020\} Available from: http://www.iamj.in/posts/images/upload/2505_2509.pdf 